\title{
Exploring Community Philosophy as a tool for parental engagement in a primary school
}

DOI 10.1515/ijtr-2015-0011

received June 2015; accepted September 2015

\begin{abstract}
In this paper, I will reflect on the initial reconnaissance, action, and reflection cycle of my doctoral research, exploring Community Philosophy as a tool for critical parental engagement in a primary school (Elliot, 1991). I will examine how I reflexively engaged with my influence on participants, which then significantly influenced the framing of, and the planning for, the second action research cycle.
\end{abstract}

The challenges that the initial stages of my research have presented will be considered using Herr and Anderson's five components of validity (Herr and Anderson, 2014). I then use the four Chronotopes of Research developed by Kamberelis and Dimitriadis (2005) to discuss the implications for my understanding of positioning, authenticity and transformation, and the resultant reframing of my research.

In order to set the context for my research, I begin by giving a brief overview of my own interest in 'democratic voice'. This is followed by an exploration of the current 'closing the gap' discourse in English education (OFSTED, 2013; Social Mobility and Child Poverty Commission, 2014; Wilshaw, 2013), to demonstrate how parental engagement has become individualised, lacks democratic voice, and often valorises middle class parents. Hence I will argue that there is a need for a more democratic and collective model of parental engagement, and make a case for justifying Community Philosophy as a possible model.

Keywords: Community philosophy, parental engagement, primary school, critical participatory action research

\footnotetext{
*Corresponding author: Charlotte Haines Lyon, Post Graduate Stu-
} dent, York St John University, UK. Email: c.haineslyon@yorksj.ac.uk

\section{Introduction}

With a background in community work, democratic voice has always been important to me. Particular projects have included: working with young people to shape council environment policy; building relationships between an Age Concern Day Centre, the local church and the primary school; and working with churches to shape National Minimum Wage legislation.

More recently I have worked as a grass roots craft tutor with the Craft Guerrilla Collective in London and with locals in North Yorkshire. We have endeavoured to provide space for ideas and points of entry for those who are sometimes excluded from the traditional craft establishment. This has included pop up workshops in cafes, pubs and nightclubs and the use of readily available materials rather than expensive 'professional' equipment. There is an emphasis on participants sharing ideas, teaching each other and shaping future workshops.

When my children started school, I was struck by the lack of voice parents had. There were opportunities to raise money, to fill in homework books, and in primary schools to volunteer to work with children. However, too often parents are placed in a supportive role rather than being a person who might have something to offer a dialogical relationship. Whilst the word 'partnership' is often espoused, one side of the partnership, the school, has more influence than the other.(Reay, 2008; 2006; Vincent, 1996; Vincent and Tomlinson, 1997; Westergård and Galloway, 2010).

Whilst it is possible to become a parent governor (I am vice chair of governors at my daughters' school), these roles are diminishing. New regulations in 2012 laid down the expectation of all English maintained schools to reconstitute their governing bodies by 2015 (Department of Education, 2015). As a result most governing bodies have become smaller, with fewer parent governors. In addition, there is an emphasis on the skills set of governing bodies rather than representation, providing for an increasing professionalisation of governors (Wilkins, 2014). This echoes McClain's criticism of schools assuming that only certain parents (middle class professionals) are able to 
be involved in "educational strategizing" (McClain, 2010: 3075).

A further erosion of democratic voice for parents was demonstrated by the current Education Secretary, Nicky Morgan, pledging to remove the right of parents to have a judicial review of a school's enforced conversion to an academy (Adams and Perraudin, 2015). It appears that parent voices are rarely valued beyond the individual relationship between the school and child, too often assumed to be homogenous, and that some voices are seen as more acceptable than others (Lumby, 2007; McClain, 2010: 3075; Reay, 2008).

\section{Closing the Gap}

In recent years, 'closing the gap' has become central to education policy. The UK has performed badly in international tables charting inequality. Many agencies have demanded action to close the gap between the most deprived children and their peers (Department for Children, 2008; 2009b; 2009a; Department for Education, 2011; Field, 2010; H M Government, 2011; Milburn, 2014; OECD, 2010; Save the Children Fund, 2012; Social Mobility and Child Poverty Commission, 2014).

A common theme to reports and speeches on 'Closing the Gap' is that parents have a role to play. However, such a role is ill-defined and problematic; demands for various forms of parental engagement ignore deep structural inequalities or the need for resources. Furthermore, terms such as 'deprived', 'disadvantaged' and 'free school meals eligibility', are conflated with 'working class' (Perry and Francis, 2010). Much of the discourse places parents, especially poor and/or working class parents in deficit and assumes they have no or little agency, let alone a will or ability to aspire to and achieve more. The Chief Inspector of Schools in England asserts that for disadvantaged pupils, "poverty of expectation is a greater problem than material poverty" (Wilshaw: 3, emphasis in the original).

Both OFSTED and the Social Mobility and Child Poverty Commission have said that effective parenting and specific parenting styles are key to closing the gap, and advocate attention is paid to parenting (OFSTED, 2013: 36; Social Mobility and Child Poverty Commission, 2014). This seems to individualise the problem and blame parents without any regard to the structural problems that may be affecting parents.

It was also suggested that "Parents have a responsibility to move into employment where they can reasonably be expected to and take steps to increase their earnings to protect living standards ..." (Social Mobility and Child Poverty Commission, 2014: 6). This seems particularly perverse in an age of austerity, where public sector pay is effectively frozen. Furthermore, it is clear that aspiration is individualistic and not socially and community orientated (Jones, 2015).

However, there are now an increasing number of voices critiquing the individualistic discourse in education and arguing for a more collectivist approach (Perry and Francis, 2010; Reay, 2012). Hartas advocates an approach "which considers parents to be capable of acting and thinking together to tackle inequality in ways relevant to their communities" (Hartas, 2012: 4).

My research builds on such a collective imperative, by way of starting a Community Philosophy Group within a school community. Participating parents and carers are critically exploring issues pertaining to parental engagement and closing the gap. The initial participants are working collaboratively work with me on the project, and it is hoped they will increasingly facilitate the group, and eventually sustain it themselves. Closing the gap has been chosen as a focus, as it provides much to discuss and critique in terms of the shape of parental engagement.

Furthermore, critical discussion of closing the gap may benefit the community, as research has shown that parental engagement shaped within local communities is most effective (Desforges and Abouchaar, 2003; Dyson A et al., 2010; Goodall et al., 2011; Mongon, 2013; Perry and Francis, 2010).

\section{Community Philosophy}

Community Philosophy (CP) is a form of group discussion that critically explores concepts, builds arguments, engages in reflection, and considers possible action to be taken by participants. It is related to Philosophy for Children (P4C) which is used extensively in schools (SAPERE, 2015).

As with P4C, developed by Matthew Lipman, CP draws on Socratic questioning to examine the world around us and works with a similar methodology, including: a stimulus, setting a philosophical agenda, and dialogue. Both $\mathrm{P} 4 \mathrm{C}$ and $\mathrm{CP}$ value action as an outcome, whether individual or collective, rather than a specific consensus. It is for this reason I wanted to use it for parental engagement, as it takes a collective parents meeting beyond being a "moaning shop" (a key concern of both the headteacher and the parents with whom I am working). 
The name 'Community Philosophy' emphasises the community that the group is situated in, rather than the community of inquiry that the group may become. Tiffany argues that this implies that the community is the actor rather than passively receiving philosophy (Tiffany, 2009: 22). Again it was important to me to have a model of parental engagement that placed the parents as actors rather than victims or people lacking competence, thus needing something doing to them. Because of my own background experience and values, I believed it was also important to have a model that valued the community, rather furthering the discourse of individualism. In fact Lipman, when developing Philosophy for Children, argued that his method valued "reasonableness" over "rationality", as the former implies that participants had to take other people in to account (Lipman, 2011).

Lipman drew on Dewey's idea of democracy being ". . .more than a form of government; [but rather] primarily a mode of associated living, of conjoint communicated experience.” (Dewey, 1916: 87). Furthermore, Benhabib and Yeatman argue that there is a need for collective critique of institutions and authorities, and deliberation of different voices, in order to determine what is good, and also to legitimise such establishments (Benhabib, 1996; Young, 1996). I believe that CP might play this kind of role within the school community.

It was with all this in mind that I developed a plan to work with parents at a primary school to start a Community Philosophy Group. One of the aims of CP is that participants increasingly become responsible for facilitating the group; and similarly I am hoping that parents will start to facilitate the group, so that in the long term it will become self-sustaining (SAPERE, 2015).

\section{The Research Project}

The aim of my research project is to examine Community Philosophy as a tool for critical engagement of parents and their collective voices in a primary school. The community chosen is part of a coastal town, as coastal towns were specifically mentioned by OFSTED as problematic regarding having a large attainment gap between the poorest children and their peers (OFSTED, 2013).

The research will seek to answer the following research questions:

- How can CP provide a forum for group discussion and development of collective parental voices?

- How, if at all, does CP allow problematising and reshaping of parental engagement?
- How, if at all, can CP enable parents to develop strategies and actions to further develop parental engagement in the school community and its wider community?

- How, if at all, does CP encourage action taking that promotes social justice within the school community?

- How does CP affect parental participation, especially with regard to unheard voices?

- How, if at all, does CP foster harmonious relationships within the school community?

- How can CP become self-sustaining in the setting?

The research is promoting democratic principles, catalysing action, and also attempting to counter the individualism seemingly encouraged in education. Therefore it was imperative to employ a research methodology that does not claim to be 'objective', but instead embraces the significance of values in the research process; and in this particular context, recognises the significance of political values. Action Research met these criteria. As Gergen and Gergen argue: "It is not the task of the action researcher to describe the world as it is, but to realize visions of what the world can become" (Gergen and Gergen, 2013: 167).

Action Research includes a range of different approaches to value-based research, including Practitioner Research, Co-operative Inquiry, Action Science, Community Action Research and Participatory Action Research (Herr and Anderson, 2014; Reason and Bradbury, 2008; Stringer, 2014). The common thread is the reflective cycle or spiral in which the researcher, and in many cases the participants, make a plan, followed by action, reflection and then more planning (Kemmis et al., 2014; Koshy, 2009; Opie and Sikes, 2004; Stringer, 2014).

Kemmis et al have developed the idea of 'Critical Participatory Action Research', which emphasises the critical nature of "exploring social realities in order to discover whether social or educational practices have such untoward consequences" (Kemmis et al., 2014: 16). This understanding of Critical Participatory Action Research seemed particularly appropriate for this project, as the aim of the Community Philosophy group is not simply to devise actions, but also to explore critically the world around it. The nature of such critical exploration will be further explored later.

Whilst Greenwood and Levin argue that the furthering of democracy is an imperative for Action Research, some action research is far more practitioner centred (Greenwood and Levin, 1998). As the focus of my research is not solely my own practice, but that of a group of us working together, it felt important to emphasise this by developing the idea of "participatory action research". 
However the research is not just action, but is also central to my $\mathrm{PhD}$. The process of researching therefore needs to meet the rigorous standards of doctoral study, and to make an original contribution to knowledge. It is this tension between the academic standards required of me, and the very different needs of other participants, that has provided the most interesting food for thought as a researcher. The next section will explore this further.

\section{Validity, Reflexivity and Prelimi- nary Fieldwork}

Herr and Anderson claim that in Action Research there are five components to validity; process validity, democratic validity, catalytic validity, dialogic validity, and outcome validity (Herr and Anderson, 2014). This section uses each of these components as a heuristic device to explore how I grappled with concerns about the research, including mitigating reflexive strategies to show how they played out in the preliminary fieldwork.

The fieldwork discussed below comprises:

- two informal ad hoc interactions with parents at a nursery singalong, which aimed to gain information as to how best set up a Community Philosophy Group.

- one meeting, arranged in conjunction with the headteacher and three parents and guardians, to explore setting up a CP group.

- the first CP meeting.

\section{Process Validity}

Herr and Anderson argue that process validity requires research to demand "ongoing learning" which in turn implies the need for a "series of reflective cycles that include the ongoing problematization of the practices under study?" (Herr and Anderson, 2014: 68)

To help address process validity, I have built in reflective cycles throughout the project using personal reflexive strategies, but also group reflection alongside triangulation which will involve interviews with participants and the headteacher. Whilst there is a reflective process involved in every group meeting, I will also build in a wider cycle every few meetings, in which the whole group reflects on its work and plans for the next stage.

As Bolton argues, reflexivity enables the researcher to make "aspects of the self strange" (Bolton, 2010: 14). This in turn allows the researcher to scrutinise their positioning, the assumptions that they are bringing to the work, and the interplay of power. It also helps to mitigate co-option and manipulation, however deliberate or unwitting, by putting distance between the researcher and their actions and thoughts, and providing opportunities to identify areas of concern.

Whilst the whole project will have particular cycles of reflection, planning and action, the following strategies will be used throughout. My aim is to allow different understandings of my research practice to be gleaned, in order to address issues as they arise or even pre-empt them.

1. Reflexive journaling: writing freely after events and carrying out specific writing exercises. Reflexive writing also takes place during and after transcribing and at other points in the process. It allows me to continually challenge my assumptions and values and has led to changes in my research practice which will be discussed later.

2. Reflection within the $\mathrm{CP}$ process. There will be reflection within individual CP sessions; part of every $\mathrm{CP}$ session is dedicated to reflection on that particular session by participants. This would include the participants considering who is missing from the group. Missing voices might include people such as head teachers and other stakeholders as well as parents. At the first CP meeting, a participant said they would like to see teachers at the meeting at some point in the future.

3. Dialogic Inquiry Tool: An aide memoire will be used, based on the Dialogic Inquiry Tool developed by Reznitskaya (2012: 450) to evaluate the dialogue within Philosophy for Children sessions. Part of the tool is shown below: it includes questions about the quality of authority, questioning, feedback and explanations within the group.

I use the term 'aide memoire' advisedly, as I am not convinced that individual scores are helpful in terms of a precise measurement. However, it does highlight areas that might be problematic or that have changed over time, and also helps to plan for future sessions.

Using this after the first CP session helped me realise that I was so concerned about not controlling the session, I had not facilitated and led enough, considering it was the start of the process. I hope that later in the project, the group will use this tool to evaluate the working practices together, as part of a wider reflective cycle. 


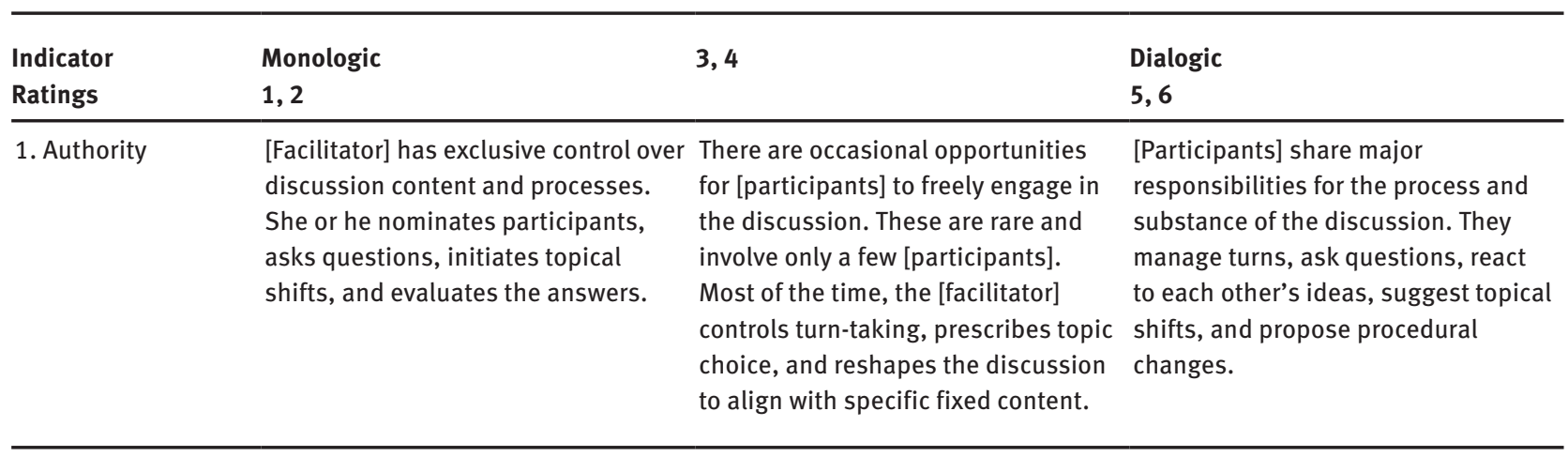

Figure 1: (Reznitskaya, 2012: 450)

\section{Democratic Validity}

It is essential that this research is democratic in name and practice. Whilst using terms such as participation and democracy, it is still possible to side-line and misappropriate participants' words and actions. For example the school and I could say that we had worked with parents, when in fact we technically listened to them, but ignored them. I was anxious to avoid co-option, despite exhortations of democracy and participation (Denzin, 2010; Fals Borda, 2013; 2006; Freire, 1982; Gergen and Gergen, 2013; Herr and Anderson, 2014).

It will be essential to foreground my research and $\mathrm{PhD}$ at every CP session, so that people don't forget it is not simply a CP group. Nevertheless, I am keen to involve participants coding transcripts further down the line and “member check" where practicable (Torrance, 2012). Due attention will be paid to those whose voices are being heard, and in turn reported. Are they happy with how their voices are used in my research?

Initially, I was very concerned about my status as an outsider. It seemed particularly strange to be carrying out critical participatory action research as an outsider; was it possible to be truly participatory when I was making an intervention in a school community that I did not know? Would it be a case of an outsider influencing a group of people who had no influence on the research?

Herr and Anderson argue for a "Continuum of insider/ outsider Positionality" of 1-6; 1 being an insider researching one's own practice and 6 being an outsider studying insiders (Herr and Anderson, 2014: 44ff). I placed my positionality as 5, "Outside in collaboration with insiders", but would hopefully move towards 4, "Reciprocal collaboration" for at least some of the project. Towards the end of the project, during the handover phase, the positionality might move further to outsider status.
A further concern regarding relationships was manipulation. As Duncombe and Jessop warn, there is a risk of manipulation in order to achieve results (Duncombe and Jessop, 2002). Having a community work background, I am experienced in building friendly relationships, but do I risk commodifying rapport and friendly relationships with participants in the name of collaboration, in an attempt to get the results I want? I hope that both the group reflection processes and my own reflexive journaling will help mitigate this.

With reflexive strategies in place, I had written extensively beforehand about my assumptions and concerns. I felt prepared to meet with parents; however, as I drove to the singalongs, I realised that I hadn't prepared how to say hello to them or how to introduce myself or my research. How was I going to hook them? "Hook" seemed obviously inappropriate and panic ensued.

On entering an anteroom full of families waiting to watch their children sing, I realised that this was my chance to talk to parents, and I wasn't going to be introduced by anybody else. Consequently, I stumbled through the first 10 minutes, and repeated the exercise in the afternoon with a little more aplomb.

Having committed to reflexive journaling throughout the research, after each session with parents, I sat down and wrote. Following Bolton's advice, I wrote freely for 10 minutes, and then I wrote letters that I imagined the people I spoke to might write to me (Bolton, 2010). This was illuminating. One realisation was that, having endeavoured not to "hook" people, I had not, in the process, made much sense in explaining the research. I was apologetic about wasting their time. I had assumed no interest. I had assumed they would be suspicious of someone from university, or someone from outside. All of these, of course, revealed unrecognised assumptions of my own. 


\section{Catalytic Validity}

This refers to how both the participants and the researcher critique and act upon their situation. What is the transformation that is experienced? I realised my discomfort at regarding "hook", was in trying to explain to people that they were victims, and Community Philosophy was going to save the day. As I researched issues around 'closing the gap', I became increasingly angry at the government, OFSTED and the Social Mobility and Poverty Commission's rhetoric on parental engagement. The positioning of parents either as feckless or inept, especially if they weren't middle class professionals exasperated me. I saw them as victims of the "system".

Kemmis and Mactaggart claim that participatory action research enables dialogue and "a collaborative practice of critique” (Kemmis and McTaggart, 2008: 297). I built on this and began to see the project using $\mathrm{CP}$ as a way for participants to discover the malevolent discourses at work, and the assumptions the government were making about parents. I hoped that parents would rationally critique this, discover the truth, and come up with a better plan. I saw this as following a Freirian route to conscientization (Freire, 1972). However I began to take heed of Gillies and Alldred warning against the dangers of assuming "false consciousness", and recognised that it is possible that $\mathrm{C} P$ exacerbates this danger, as it emphasises rational critical discussion (Gillies and Alldred, 2002).

\section{Dialogic Validity}

Dialogic validity refers to the need for my research to engage with some form of peer review with other researchers, not just with participants. Supervision, exploration with fellow students, and engagement with the Collaborative Action Research Network at my university help me work towards this.

After the first $\mathrm{CP}$ meeting, a participant withdrew from the project expressing concern that it would become "a slagathon" about the school and she felt disloyal. A "slagathon" was exactly what I hoped that the CP process would prevent, hence I was utterly disappointed that I had seemingly failed with this participant. As the consent process had emphasised the right to withdraw, I felt unable to pursue this with them.

Talking this through with fellow action researchers and also at a faculty seminar, I was helped me to understand that both I and the participants hold a multitude of positionalities. Mine include being a student, mother, feminist, socialist, and political debater. Different participants will hold a wide range of positionalities between them, including experiences of debate and critique. As Vincent argues, "In a culture of public political passivity we are not used to voicing our opinions publicly and in relation to others" (Vincent, 2012). I am now considering how to negotiate the multiple positionalities of participants as well as my own.

\section{Outcome Validity}

Tiffany asserts that Community Philosophy can only be judged by the actions that it leads to, rather than the reasoning that occurs within (Interview in Evans, 2012). Outcome validity assesses whether the intervention worked; did it achieve what it set out to do?

Whilst I will be using the answers to my research questions as part of outcome evaluation, Torrance raises the question, for whom has the research worked? (Torrance, 2012). Has the new knowledge gained benefitted the participants as well as me and/or the school or other authorities? This highlights the importance, not only of ongoing group reflection, but also the need for interviews with some participants and the headteacher to understand how they think the research may have "worked".

\section{Implications of the process so far}

This preliminary fieldwork, together with a disciplined reflexive journaling process, has helped me to readdress my positioning and that of the participants, and in turn my understanding of influence. Furthermore it has actually led to a shift in the framing of the research.

Kamberlis and Dimitriadis have developed four chronotopes or typologies of research:

1. Objectivism and Representation

2. Reading and Interpretation

3. Skepticism, Conscientization, and Praxis

4. Power/ Knowledge and Defamiliarization

(Kamberelis and Dimitriadis, 2005: 26)

Objectivism and Representation relates to a more positivistic scientific type of research in which objective truths can be found. Reading and Interpretation encompasses a more social constructionist understanding of research, in which truth is mediated by language and somewhat relativistic compared to the absolutist truth of the first Chronotope. 
The third Chronotope draws on the Critical paradigm, in that it critiques ideologies present within the constructed knowledge and the power dynamics. There is Freirian critical exploration of a situation with rational dialogue thus seeking enlightenment and conscientization.

I originally argued that my research fell mainly into this third chronotope and was assuming that the Community Philosophy would help parents to use the process of rational dialogue to unmask the unjust workings of the government and other powers that be. Through this process of conscientization and enlightenment, the participants would be able to take action to recreate more just and workable models of parental engagement.

I would now argue that the research is about co-constructing new possibilities regarding parental engagement which fits more with chronotope 4 of Power/ Knowledge and Defamiliarization. Placing people as victims denies them of the agency and assumes they are not already resisting structural oppressions (Doucet, 2011 ; Robinson and Gregson, 1992). This chronotope recognises that power is fluid, and people have the agency to act although they will also be affected by structures. Reflexivity provides defamiliarization which helps identify structures and discourse, and examine new possibilities for working (Kamberelis and Dimitriadis, 2015; 2005). The process of reflexivity and distanciation so far in my research has enabled me to see where my assumptions have caused problems and helped me identify new ways of working.

Instead of placing participants as victims of a system that they can rationally endeavour to overthrow or release themselves from, I am considering participants as colleagues who may be able to help me find appropriate local possibilities of working. It is the myriad of different experiences that they bring, that help the project to be more likely to find effective strategies for parental engagement.

\section{Authenticity}

As a result of this shift in chronotope, I reframed how I was explaining the research to parents. Now I simply needed to explain that I wanted to work with them to find effective methods of parental engagement that were appropriate to their situation, with a view to helping close the gap between the poorest children and their peers. Furthermore, previously I had been uncomfortable in using the term Community Philosophy as it sounded too academic and possibly alienating. Now I was much more comfortable in using it as it wasn't a tool for emancipation, and yet again placing participants as victims to be 'saved'. Rather I want to use Community Philosophy because I believe the methodology encourages debate and reflection in a way that helps mitigate power dynamics, and also encourages action rather than simply moaning. This felt far more authentic and easier to articulate.

Gergen and Gergen argue that such authenticity is essential to Action Research, in that the researcher articulates their values, in contrast to positivist researcher traditions in which the researcher is apparently neutral or even value free. They make the useful point that there is a difference between saying: "these are my values, and my research is trying to do this because I think it will work for the common good", and "I proclaim the universal good." (Gergen and Gergen, 2013: 165)

Armed with a more coherent strategy at the meeting with the head and three parents and carers, I simply told the parents and carers about my research, what I was doing, and that I hoped they might be interested. This time there were no blank faces; and the women helped me set up the first meeting, gave solid advice as to where we should meet, and the precise wording to put in the fliers to ensure they were inclusive of guardians and fathers. Furthermore, they embraced the concept of Community Philosophy. Acceptance and understanding was further demonstrated by parents and carers at the beginning of the first CP meeting.

Such authenticity foregrounds my values and my influence. It allows people to make informed decisions as to whether they participate.

\section{Revisiting positionality}

Ospina et al argue that not only does the researcher shift positioning, but so do participants. They also echo Herr and Anderson in saying that researchers should not concern themselves with precise positioning as much as continual reflection and honesty within their research (Ospina et al., 2008; Herr and Anderson, 2014). Hoel writes that positioning can swing like a "pendulum" (Hoel, 2013: 32). The participants need to negotiate their positioning themselves rather than me position them, and it needs to be recognised that both the researcher and participants hold a range of fluid positions in any given moment.

Participants are not a homogenous entity, but a variety of individuals with different talents, experiences and life stories. Moreover, they are quite capable of telling me they are or are not interested in getting involved with the project. I am now starting with a position that assumes the parents have the agency to do this rather than being 
victims of the system. However, I am still recognising that there needs to be a critique of power relationships, structures and systems that may inhibit or even shape such agency at times (Kamberelis and Dimitriadis, 2005). More importantly, however, I am not fixing participants into a dichotomy of agents or victims, but that there is ability to be one, the other or both. This moves further away from me directly influencing participants, but rather working with them together on a project in which we might all have influence.

\section{Conclusion}

The initial aim of this research project was to make a political intervention, in that it was problematizing the government's discourse on parental engagement. It was hoped that parents would take part in Community Philosophy, critique the discourse and design a more socially just plan. However I was assuming a certain lack of agency on behalf of the parents and that they needed to be conscientized. With the use of reflexive exercises, I realised that this was problematic in terms of how I was positioning participants, and not particularly ethical in terms of how I was influencing them. I was also denying their influence.

The research has now shifted in its aim, albeit subtly. Whilst there is still a place for critical thought and questioning of power relations, the starting assumption is that participants and I will work together to create new possibilities in parental engagement. This act in itself is political; collectively exploring the current discourse that often assumes lack of agency on behalf of parents and seeks to individualise parents.

The emphasis is now on the agentic co-construction of knowledge, rather than the transformation of participants. This is not to deny that transformation will occur. However I am no longer hoping for participants to be transformed through conscientization; from a false consciousness to enlightenment. Rather I understand transformation as a continual process of change that affects both myself, individual participants and the group of participants as a whole. Transformation may be seen in other ways too, in terms of new understandings/ forms of parental engagement in the school and community, and as the result of other actions.

My initial desire to use the term Participatory Action Research was out of a need to underscore the involvement of participants in the research. However I now understand it to mean the participation of myself and participants in the process of reflection, co-construction of knowledge, action and change. Furthermore the use of term of Critical Participatory Action Research was to highlight a collective critique of an oppressive system; now I would understand it to mean critiquing how we are positioned in the world around us, and how we as actors negotiate the different discourses in the world.

\section{References}

[1] Adams, R. and Perraudin, F. (2015). Education Bill to Close Loopholes' Blocking Academies Expansion. The Guardian. London, UK: Guardian Media Group. http://www.theguardian. com/education/2015/jun/03/education-bill-loopholesacademies-schools (Accessed 6th October 2015)

[2] Benhabib, S. (1996). Democracy and Difference: Contesting the Boundaries of the Political, Princeton, USA: Princeton University Press.

[3] Bolton, G. (2010). Reflective Practice: Writing and Professional Development, London, UK: Sage.

[4] Denzin, N. K. (2010). The Qualitative Manifesto, a Call to Arms, Walnut Creek, USA: Left Coast Press Inc.

[5] Department for Children, Schools and Families. (2008). The Impact of Parental Involvement on Children's Education. London, UK: Crown Copyright.

[6] Department for Children, Schools and Families. (2009a). The Extra Mile (Secondary) Achieving Success with Pupils from Deprived Communities. Nottingham, UK: DCSF Publications.

[7] Department for Children, Schools and Families. (2009b). Breaking the Link Betwen Disadvantage and Low Attainment: Everyone's Business. Nottingham, UK: DCSF Publications.

[8] Department for Education. (2011). Pisa 2009 Study: How Big Is the Gap? A Comparison of Pupil Attainment in England with the Top-Performing Countries. London, UK. Crown Copyright

[9] Department of Education. (2015). The Constitution of Governing Bodies of Maintained Schools. Statutory Guidance for Governing Bodies of Maintained Schools and Local Authorities in England. London, UK: Crown Copyright.

[10] Desforges, C. and Abouchaar, A. (2003). The Impact of Parental Involvement, Parental Support and Family Education on Pupil Achievement and Adjustment : A Review of Literature, Nottingham, UK: Department for Education and Skills. http://bgfl.org/bgfl/custom/files_uploaded/uploaded_ resources/18617/desforges.pdf (Accessed 6th October 2015)

[11] Dewey, J. (1916). Democracy and Education, London, UK: The Free Press.

[12] Doucet, F. (2011). (Re)Constructing Home and School: Immigrant Parents, Agency, and the (Un)Desirability of Bridging Multiple Worlds. Teachers College Record 112: 2705-2738.

[13] Dyson A, Goldrick S, Jones L, Kerr, K. (2010). Equity in Education: Creating a Fairer Education System. Manchester, UK: Centre for Equity in Education,University of Manchester http://www.seed.manchester.ac.uk/medialibrary/Education/ research/cee/publications/equity_in_education.pdf (Accessed 15th July 2015) 
[14] Evans, J. (2012). Connected Communities - Philosophical Communities. London, UK: Queen Mary, University of London, Arts and Research Council.

[15] Elliot, J. (Action Research for Educational Change. Buckingham, UK: Open University Press.

[16] Fals Borda, O. (2006). The North-South Convergence: A 30-Year First-Person Assessment of PAR. Action Research 4: 351-358.

[17] Fals Borda, O. (2013). Action Research in the Convergence of Disciplines. International Journal of Action Research 9: 155-167.

[18] Field, F. (2010). The Foundation Years: Preventing Poor Children Becoming Poor Adults. London, UK: HM Government. http:// webarchive.nationalarchives.gov.uk/20110120090128/http:// povertyreview.independent.gov.uk/media/20254/povertyreport.pdf (Accessed 6th October 2015)

[19] Freire, P. (1972). Pedagogy of the Oppressed, Harmondsworth, UK: Penguin Books.

[20] Freire, P. (1982). Creating Alternative Research Methods; Learning to Do It by Doing It. In: Hall B. L., Arthur G. and Rajesh T. (eds) Creating Knowledge : A Monopoly? (pp29-40). New Delhi, India: Society for Participatory Research in Asia.

[21] Gergen, K. and Gergen, M. (2013). Social Construction and Research as Action. In: Reason P. and Bradbury H. (Eds.) Handbook of Action Research(pp159-171). 2nd Paperback ed. California, USA: Sage.

[22] Goodall, J., Vorhaus, J., Carpentieri, J., Brooks, G., Akerman, R. and Harris, A. (2011). Review of Best Practice in Parental Engagement. London, UK: Department for Education.

[23] Greenwood, D. J. and Levin, M. (1998). Introduction to Action Research: Social Research for Social Change. London, UK: Sage Publications.

[24] H M Government. (2011). Opening Doors, Breaking Barriers: A Strategy for Social Mobility. London, UK: Cabinet Office.

[25] Hartas, D. (2012). The Achievement Gap: Are Parents or Politicians Responsible. Bera Insights Autumn 2012.

[26] Herr, K. and Anderson, G. (2014). The Action Research Dissertation : A Guide for Students and Faculty, London: Sage.

[27] Hoel, N. (2013). Embodying the Field: A Researcher's Reflections on Power Dynamics, Positionality and the Nature of Research Relationships. Fieldwork in Religion 8: 27-49.

[28] Jones, O. (2015). Don't Let the Tories Steal Aspiration We on the Left Must Claim It. The Guardian. London, UK: Guardian Media Group. http://www.theguardian.com/ commentisfree/2015/may/12/tories-aspiration-labourambition-conservatives (Accessed 6th October 2015)

[29] Kamberelis, G. and Dimitriadis, G. (2005). Qualitative Inquiry, Approaches to Language and Literacy Research, New York, USA: Teachers College Press.

[30] Kamberelis, G. and Dimitriadis, G. (2015). Chronotopes of Human Science Inquiry. In: Denzin N. K. and Giardina M. D. (eds) Qualitative Inquiry-Past, Present, and Future: A Critical Reader. Walnut Creek, USA: Left Coast Press, 41-68.

[31] Kemmis, S. and McTaggart, R. (2008). Participatory Action Research, Communicative Action and the Public Sphere. In: Denzin N. K. and Lincoln Y. S. (Eds.) Strategies of Qualitative Inquiry pp(271-330). 3rd ed. London, UK: Sage Publications,.

[32] Kemmis, S., McTaggart, R. and Nixon, R. (2014). The Action Research Planner : Doing Critical Participatory Action Research, London, UK: Springer.

[33] Koshy, V. (2009). Action Research for Improving Educational Practice: A Step-by-Step Guide. Sage Publications Ltd.
[34] Lipman, M. (2011). Philosophy for Children: Some Assumptions and Implications. Ethics in Progress Quarterly 2.

[35] McClain, M. (2010). Parental Agency in Educational Decision Making: A Mexican American Example. Teachers College Record 112 (12), 3074-3101.

[36] Milburn, A. (2014). State of the Nation 2014. London: Social Mobility and Child Poverty Commission.

[37] Mongon, D. (2013). Educational Attainment: White British Students from Low Income Backgrounds. London, UK: OFSTED. http://webarchive.nationalarchives.gov.uk/20141124154759/ http://www.ofsted.gov.uk/resources/access-and-achievementbackground-papers (Accessed 6th October 2015)

[38] OECD. (2010). Pisa 2009 Results: Overcoming Social Background - Equity in Learning Opportunities and Outcomes (Volume II). http://dx.doi.org/10.1787/9789264091504-en (Accessed 6th October 2015)

[39] OFSTED. (2013). Unseen Children: Access and Achievement 20 Years On. London: OFSTED. https://www.gov.uk/government/ publications/unseen-children-access-and-achievement-20years-on (Accessed 6th October 2015)

[40] Opie, C. and Sikes, P. J. (2004). Doing Educational Research: A Guide to First-Time Researchers. London, UK: Sage Publications.

[41] Ospina, S., Dodge, J., Foldy, E. and Hofmann-Pinilla, A. (2008) Taking the Action Turn: Lessons from Bringing Participation to Qualitative Research. In: Reason P. and Bradbury H. (Eds.) The Sage Handbook of Action Research: Participative Inquiry and Practice (pp 420-434). 2nd ed. London, UK: SAGE,

[42] Perry, E. and Francis, B. (2010). The Social Class Gap for Educational Achievement: A Review of the Literature. London, UK: RSA Projects.

[43] Reason, P. and Bradbury, H.(Eds.) (2008). The Sage Handbook of Action Research: Participative Inquiry and Practice. London, UK: SAGE.

[44] Reay, D. (2006). The Zombie Stalking English Schools: Social Class and Educational Inequality. British Journal of Educational Studies 54: 288-307.

[45] Reay, D. (2008). Tony Blair, the Promotion of the "Active" Educational Citizen, and Middle-Class Hegemony. Oxford Review of Education 34: 639-650.

[46] Reay, D. (2012). What Would a Socially Just Education System Look Like?, London, UK: Studies Centre for Labour Studies, http://classonline.org.uk/docs/2012_Diane_Reay_-_a_ socially_just_education_system. (Accessed 15th July 2015)

[47] Reznitskaya, A. (2012). Dialogic Teaching: Rethinking Language Use During Literature Discussions. The Reading Teacher., 65:7:446-456.

[48] Robinson, F. and Gregson, N. (1992). The 'Underclass': A Class Apart? Critical Social Policy 12: 38-51.

[49] SAPERE. (2015). Community Philosophy. http://www.sapere. org.uk/Default.aspx?tabid=102 (Accessed 6th October 2015)

[50] Save the Children Fund. (2012). Closing the Achievement Gap in England's Secondary Schools. London: Save the Children.

[51] Social Mobility and Child Poverty Commission. (2014). How the Key Players Outside Central Government Can Tackle Child Poverty and Promote Social Mobility. London: SMCPC. https://www.gov.uk/government/publications/ how-the-key-players-outside-central-government-can-tacklechild-poverty-and-promote-social-mobility (Accessed 6th October 2015) 
[52] Stringer, E. T. (2014). Action Research, Los Angeles, USA: Sage.

[53] Tiffany, G. (2009). Community Philosophy, a Project Report. Reflections on the Joseph Rowntree Foundation's New Earswick Community Philosophy Project. York: Joseph Rowntree Trust. https://www.jrf.org.uk/report/community-philosophy-projectreport (Accessed 6th October 2015)

[54] Torrance, H. (2012). Triangulation, Respondent Validation, and Democratic Participation in Mixed Methods Research. Journal of Mixed Methods Research 6: 111-123.

[55] Vincent, C. (1996). Parents and Teachers: Power and Participation, London: Falmer.

[56] Vincent, C. (2012). Text for Inaugural Lecture: Parenting in the Twenty-First Century: Responsibilities, Risks and Respect.: Institute of Education.

[57] Vincent, C. and Tomlinson, S. (1997). Home-School Relationships: 'The Swarming of Disciplinary Mechanisms'? British Educational Research Journal 23: 361-377.
[58] Westergård, E. and Galloway, D. (2010). Partnership, Participation and Parental Disillusionment in Home - School Contacts: A Study in Two Schools in Norway. Pastoral Care in Education 28: 97-107.

[59] Wilkins, A. (2014). Professionalizing School Governance: The Disciplinary Effects of School Autonomy and Inspection on the Changing Role of School Governors. Journal of Education Policy 30: 182-200.

[60] Wilshaw, M. (2013). Unseen Children - HMCI Speech. http:// webarchive.nationalarchives.gov.uk/20131216154121/https:// www.ofsted.gov.uk/resources/unseen-children-hmci-speech. (Accessed 15th July 2015)

[61] Young, I. M. (1996). Communication and the Other: Beyond Deliberative Democracy. In: Benhabib S. (Ed). (1996) . Democracy and Difference; Contesting the Boundaries of the Political (pp.120-135) Chichester, UK: Princeton University Press. 